\title{
THE IMPACT OF MULTINATIONAL BANKS ON DEVELOPMENT FINANCE
}

\author{
Christian E. Weller \\ Center for European Integration Studies \\ University of Bonn \\ Walter-Flex-Str.3 \\ 53111 Bonn GERMANY \\ E-mail: Christian_Erik_Weller@yahoo.com \\ and \\ Mark J. Scher \\ Department of Social and Economic Affairs \\ United Nations \\ Two United Nations Plaza \\ New York NY 10017
}

\section{$\underline{\text { Abstract }}$}

Financial market recommendations for less industrialized economies, particularly in the wake of the recent financial crises, have included a push for more international financial competition. The entry of multinational banks (MNBs) into developing economies is supposed to create more market discipline for domestic banks, thus making them more efficient, and enhancing financial stability. Using data from the BIS and the IMF, we look at the impact of MNBs on credit supply and on financial stability in less industrialized economies. MNBs focus their activities predominantly on serving MNCs, and on providing services that domestic banks cannot offer to domestic corporations, and high net worth individual. This increased competition in certain low risk market segments entices domestic banks to lower their credit exposure in the early stages of international financial competition. However, as MNBs continue to operate and to grow their market shares in less industrialized economies, domestic banks become more confident with the new competitive situation, eventually increasing their loans, especially to the enterprise sector. Both consequences of increased international financial competition - early credit crunches, and later credit growth - can have real implications in the form of lowered business investment or financial instabilities, unless adequate regulatory and supervisory structures are installed.

\section{Acknowledgements}

We are grateful to the participants of the Expert Group Meeting on Development and the Financial Sector: Effectiveness, Equity and Vulnerability at the U.N., and of the Research Seminar at the Center for European Integration Studies for stimulating and inspiring discussions of earlier drafts. We are particularly indebted to Adrian Tschoegl, Ken Kletzer, Barry Hermann, Rob Scott, and Robert MacCulloch for their helpful comments and suggestions on earlier versions 
of this paper. All remaining errors are our sole responsibility. 


\section{Introduction}

Financial policy recommendations for developing economies, particularly in the wake of the recent financial crises, have included a push for more international financial competition. By the end of the 1997, one of the most comprehensive agreements on trade in financial services, which covers multinational banks (MNBs), the General Agreement on Trade in Services (GATS) has been negotiated at the WTO. Consequently, while both international and multinational banking have grown in recent decades, banks in industrialized economies have increasingly emphasized lending within over cross-border lending to less industrialized economies. By mid1998 , banks in BIS member countries lent a total of $\$ 850$ billion abroad, whereas loans of their branches and subsidiaries amounted to $\$ 242$ billion. Not surprising, then, MNB activities in less industrialized economies have grown on average by double or even triple digit rates in all areas of the world since the mid-1980's, leading to a sizable market share for MNBs such as a share close to $20 \%$ of banking market assets in Chile and Argentina.

The impact of MNBs on credit supply and financial stability in less industrialized economies is contested. Proponents of more financial competition assert that MNB entry increases market discipline, the efficiency of domestic banks, and thereby financial intermediation, and the supply of credit (Fry, 1995; BIS, 1988). Greater efficiency in loan allocation should stabilize the banking system as banks become better at evaluating borrowers. Others, however, argue that a growing MNB presence may indeed induce domestic banks to lend more, but for riskier projects as they become less prudent in their activities under mounting competitive pressures (Demirgüc-Kunt and Detragiache, 1998). In this view, expanding loan 
exposure of domestic banks leading to greater financial instabilities ensue from more speculative financing in the wake of greater international financial competition. Thirdly, the opposite argument, namely that domestic banks tend to lend less if they are facing more international competition as one would expect with an Ainfant industry@, has also been put forth (Weller, 1999c). By virtue of a reduced credit exposure, banks in less industrialized economies should become more stable as the most stable banks are the ones that do not lend.

With international agreements, such as GATS, in place to pave the way for even greater MNB presence in less industrialized economies, understanding their exact impact on credit supply and financial stability is obviously not only an academic undertaking. Should the impact of international financial competition be to raise the amount of credit by making domestic banks more efficient, more international barriers to the movement of MNBs should fall. However, if the impact of international financial competition is to reduce the amount of credit available for investments, or to increase the amount for speculative financing, policymakers might want to proceed cautiously with further reductions in capital movements.

To understand the impact of a growing MNB presence on less industrialized economies, we provide first some background on MNBs, on the determinants of MNB presence, and on their activities in section II. Then, we continue by discussing the effects of MNB presence on credit supply and financial stability in section III. Finally, a few concluding remarks follow in section IV.

\section{Background}

\section{II.1 The Recent Growth of MNBs}


MNBs are understood here as banks, which establish operations in more than one country. Hence, MNBs are also sometimes referred to as foreign banks or are comprised in the general category of foreign direct investment (FDI) in financial services. In contrast, international banks are banks, which operate across international borders, but which do not establish a physical presence in other countries. MNB operations can come in different forms, namely as branch offices, as subsidiaries, as joint ventures, or as strategic partnerships. Branch offices, for instance, are an integral part of the mother company, that is, they have no capital of their own. Subsidiaries, however, are their own corporate entities, which are fully owned by the mother company, but chartered in the host economy. Similarly, joint ventures are separate corporate entities owned jointly by more than one mother company. For instance, Dresdner Bank and Banque National de Paris have been establishing a number of joint ventures in emerging economies over the past few years. Finally, MNBs may establish a strategic partnership by buying a majority stake of an already existing domestic bank. The main difference between the various operational forms of MNBs is their regulatory treatment, as banks, which are domestic corporate entities may receive a different treatment than banks which are not, similar to banks which are majority foreign owned compared to banks, which have only a minority foreign ownership share.

Most research on MNBs are hampered by their limited scope as they tend not to include more than two or three countries, and are mainly focused on the US, Japan or other Asian economies. So far, consistent data across countries has been lacking which would allow for a comparison of MNB presence. The BIS= Consolidated International Banking Statistics is 
therefore an improvement as it includes semi-annual data on international as well as multinational bank developments for a total of 184 countries and territories from 1985 to the present ${ }^{1}$. What is, however, gained in compatibility across countries has to be traded off against the drawback that the BIS provides only aggregated data for each economy without distinguishing by originating economies. Similarly, the data does not allow a distinction between the aforementioned different forms of MNB operations. Thus, while our study offers a comprehensive view of a large sample of emerging economies, its scope in investigating the determinants of MNB presence or its impact on host economies is limited by the aggregated nature of the data.

Figures compiled from the BIS= Consolidated International Banking Statistics highlight the growth in MNBs (table 1). By the end of 1998, 107 of 167 emerging economies and territories reported MNB operations. The largest recipient of MNB credit is Latin America. Further, while Asia has experienced a steady continuous growth of MNB loans between 1985 to 1997, this trend holds for the Middle East and Africa only for the 1990's ${ }^{2}$. Their growth rates pale, though, compared to those in Latin America and in Eastern Europe (table 2). Not only has MNB credit grown rapidly, it is also expanding faster than MNB deposit taking, thereby making MNBs mostly net importers of capital (table 1).

By the end of 1998, international loans to less industrialized countries amounted to $\$ 706$ billion, while MNB loans totaled about one third of that with $\$ 239$ billion, with MNBs closing in (table 2). While MNB loans have grown faster than international bank credit in all areas, MNB

${ }^{1}$ Developed economies and offshore banking centers are not included.

${ }^{2} \mathrm{MNB}$ loans and deposits from the BIS exclude foreign currency loans. Thus, where foreign 
loans still remain small on average, below $10 \%$ in Eastern Europe and the Middle East, below $20 \%$ in Asia and Africa, and at around 22\% in Latin America. The ratio of MNB credit to international bank credit is highest in Latin America with $\$ 143$ billion in MNB credit to $\$ 288$ billion in international bank loans by the end of 1998. In contrast, in the Middle East there are only $\$ 8$ billion in MNB loans and $\$ 63$ billion in international bank credit.

\section{II.2 The Determinants of MNB Presence}

currency loans are allowe, the loan figures are understating the actual size of MNB operations. 
While the numbers reveal a growing interest of MNBs in less industrialized economies, the question remains as to whether the recent growth in MNB operations can be attributed to some of the same factors found in earlier studies ${ }^{3}$. Most earlier research is based upon an application of the theory of multinational corporations (MNCs) to banking (Dunning, 1979; Gray and Gray, 1980). Based on this framework, which allows for the inclusion of economic factors beyond the firm specifics, earlier research has found a number of motivational factors for the entry of MNBs. Among these determining factors some host economy characteristics have been found to be significant, such as current account balances (Terrell, 1979; Goldberg and Saunders, 1981; Sabi, 1988, 1994), interest rate differentials (Khoury, 1979), the exchange rate (Goldberg and Saunders, 1981), market size (Terrell, 1979; Khoury, 1979), demand for MNB products (Cho, 1985), servicing MNCs (Fieleke, 1977; Goldberg and Saunders, 1981; Khoury, 1981), underdeveloped banking markets (Terrell, 1979; Khoury, 1979; Guillen and Tschoegl, 1999), the presence of other MNBs (Ball and Tschoegl, 1982; Engwall and Wallenstäl, 1988; Jacobsen and Tschoegl, 1998; Guillen and Tschoegl, 1999), real economic growth (Sabi, 1988, 1994), or country risk (Sabi 1988, 1994). Similarly, some characteristics of the originating economy seem to matter for MNBs to expand operations abroad, such as the market size of the originating economy (Terrell, 1979; Khoury, 1979), or saturated home markets (Guillen and Tschoegl, 1999). Finally, firm level characteristics appear to play a significant role, too, such as an $\mathrm{MNB}=\mathrm{s}$ knowledge of international operations and of the host economy (Ball and Tschoegl,

\footnotetext{
${ }^{3}$ Multilateral agreements, such as GATS, have made it easier for MNBs to move abroad. A greater ability to internationalize operations, however, should not be conflated with a greater
} 
1982; Ursacki and Vertinsky, 1992), or its reserve ratio (Terrell, 1979; Goldberg and Saunders, 1981).

Using a similar data as ours, Weller and Scher (1999) have analyzed the determinants of MNB presence. Their results show that host country characteristics, such as real per capita GDP growth, population, size of the banking sector or current account balances are not significant in determining MNB presence, but that lower asset prices, a ready market and competition with other MNBs may matter more than economic fundamentals in attracting MNBs.

\section{II.3 Activities of MNBs}

The activities MNBs engage in, follow from some of the determinants of their presence. Generally, MNB activities are more limited in their scope than the activities of local banks, and they tend to remain more restricted. In the early stages of MNB operations in a host economy, their operations are limited by a few factors, such as small capital base, insufficient physical and human capital, and unfamiliarity with the host economy. Over time, all these hurdles may be overcome, but in most cases, this leads MNBs to only expand in market segments, where they are already active, with the possible exception of strategic partnerships.

The market segments served by MNBs are areas where MNBs have a clear competitive advantage. One of the main reasons for MNBs to enter a new economy is to provide services to MNCs which are already their customers in other parts of the world. Further, MNBs provide services that other banks are either less familiar with or that they cannot provide. Such services include foreign currency loans, acceptances and guarantees related to international trade, or

willingness of MNBs to do so, as this depends on economic factors as well as regulatory aspects. 
syndicated loans (Brainard, 1990; Euh and Baker, 1990). Due to the nature of these services, large domestic corporations become MNB clients, whereas SMEs are less likely to require these services. Finally, MNBs offer their services to high net worth individuals to attract new deposits and to provide consumer finances. Such retail banking services include brokerage services, savings products, mortgages, credit cards or consumer loans (Brainard, 1990).

The evidence suggests that in most cases, MNBs have rarely expanded their activities beyond these market segments. For instance, when competition in traditional MNB market segments increased in Korea in the 1980's, some MNBs shut down their operations, while others expanded their activities where competition were not as fierce, in this case services to high net worth individuals, customized financing packages for corporate clients, or foreign currency loans (Brainard, 1990; Euh and Baker, 1990).

Market segments which have so far been largely ignored by MNBs are only getting a second look lately, and then only thanks to the fact that MNBs have increasingly obtained minority or majority market shares of domestic banks. For instance, since 1995 Banco Santander SA, Banco Bilbao Vizcaya SA, and Banco Central Hispano have bought large shares of almost 30 large banks in more than ten countries in Latin America, predominantly in order to offer banking services to formerly underbanked markets, such as SMEs and lower income individuals (WSJ, September 10, 1997; Guillen and Tschoegl, 1999).

The evidence on MNB activities confirms some of the findings on the determinants of MNB presence. In particular, MNBs appear to serve mainly three market segments, namely MNCs, large domestic corporations and high net worth individuals, thus supporting the finding 
that FDI flows are a significant determinant for MNB presence. The evidence further suggests that MNBs occasionally expand their activities beyond these three market segments, particularly if they obtain minority or majority shares in domestic banks.

\section{Multinational Banks, Finance Constraints and Financial Stability}

What is the impact of MNB entry and MNB operations on the domestic economy in less industrialized countries? In the previous section, we found that MNBs focus their activities on three market segments, which raises the question whether this concentration of MNBs has any effect on the behavior of domestic banks? Does it force them to become more efficient to compete with MNBs? Or does it leave them with less premium clients, and therefore more exposed to default risk? How does this impact the supply of credit and financial stability?

Based on the financial liberalization (FL) framework, it is often recommended that more foreign entrants will enhance the efficiency of domestic banks. In McKinnon=s (1973) and Shaw $=\mathrm{s}(1973)$ discussion to address the apparent excess demand for credit in less industrialized economies, a number of measures to deregulate financial markets are proposed, among them the elimination of market entry restrictions. MNB entry is particularly welcome, since it supposedly introduces market discipline, and imports foreign expertise, banking know-how and bank capital.

However, the standard FL view of international competition ignores the crucial value of information for financial firms. If borrowers and lenders do not have perfect information about each other, borrowers cannot obtain the necessary amount of finance for their investments (Stiglitz and Weiss, 1982; Gertler, 1988; Bernanke 1993). With respect to the effect of international financial competition on banks, a number of different outcomes are now possible 
that can effect the supply of credit, and possibly the stability of the domestic banking system.

The effect of a greater MNB presence on domestic banks= credit supply depends on a bank's net worth. If a bank's net worth stays above a safety threshold the bank will not increase its loans unless its net worth grows, but once its net worth falls below that safety threshold the bank will increase its loans, particularly for high risk high projects, as it stands to lose little or nothing. The dilemma, though, is that financial competition further limits banks= ability to raise their net worth, and hence they may restrict their loans if their net worth is above their safety threshold.

In liberalizing economies, domestic banks are newcomers to an unregulated market environment, and hence should be seen as an infant banking industry with large capital needs. New capital is necessary to compete, especially with MNBs, whereas the presence of MNBs limits the options to raise new capital. Specifically, more competition lowers interest rate spreads and retained earnings, and thus the most important source for new capital. In one of the most comprehensive study on the profitability of domestic banks and MNBs the authors find that @an increase in the share of foreign banks leads to a lower profitability of domestic banks@ (Claessens, Demirgüc-Kunt, and Huizinga, 1998). Thus, earlier findings by Terrell (1986) are supported, who found that banks in economies, which allow MNB entry, have lower gross interest margins, lower pre-tax profits, and lower operating costs. This limits the ability of domestic banks to raise their capital as other sources, such as public capital injections or equity issues are not readily available.

When faced with more competition and less access to capital, domestic banks may reduce 
their lending as long as their net worth remains above their safety threshold. Without a reduction in lending, greater competition and less access to capital should rise the chance of bank failure. This risk can be contained by emphasizing less risky loans over riskier ones, or by reducing lending overall. Credit to MNCs, for instance, or to large domestic corporations, is clearly less risky than to others, such as to rural producers, to small and medium-sized enterprises (SMEs), or to start-up companies. However, MNBs possess already a competitive advantage in serving less risky market segments, such as MNCs, due to their reputation or their international orientation. By virtue of their competitive disadvantages, domestic banks are then left more exposed to riskier market segments than without international competition. Consequently, few alternatives remain for sufficiently capitalized domestic banks to reduce their risk than to reduce their loans.

Credit decreases in connection with more international competition have been observed in Korea (Euh and Baker, 1990), or Poland (Weller, 1999c). In particular, the fear that some sectors are more affected than others led Korean policy makers to require that MNBs lend $35 \%$ of their loans to SMEs (Euh and Baker, 1990). Similar lending requirements have not been introduced in Hungary where the majority of the country=s banks are foreign owned, real credit has declined by $35 \%$ from 1989 to 1994 , and the financial constraints of some Hungarian borrowers are a growing concern (Anderson and Kegels, 1998; Abel, Szekely and Siklos, 1998). Finally, the case of Poland is the only one for which MNB presence has been linked to credit supply (Weller, 1999). It is found that both newly created and privatized Polish banks reduce their loans in response to a growing MNB presence, thereby also lowering total credit in Poland. 
With a decline of enterprise credit by domestic banks in the face of greater MNB presence, it is noteworthy that less loans by domestic banks only result in an overall credit decline if MNBs are not compensating for this decrease. MNBs focus their activities on serving MNC clients, large domestic corporations, and high net worth individuals. Further, MNBs are unlikely to enter more market segments, where domestic banks are reducing their loans due to $\mathrm{MNBs}=$ lack of country specific knowledge. Thus, as MNB operations are unlikely to compensate for the reluctance of domestic banks, and as domestic banks comprise the majority of the banking sector in most less industrialized economies (table 2), total enterprise credit may fall.

Up to now, we have focussed on the possibility that MNB entry leads to a credit contraction. Alternatively, MNB entry may also result in a credit expansion, possibly for unsustainable, speculative purposes. While it is argued that more international competition forces banks to become more efficient, a destabilizing role of MNB entry has lately been suspected (BIS, 1997; Kaminsky and Reinhart, 1996; Demirguc-Kunt and Detragiache, 1998). The BIS (1997:13) argues, for instance, that @financial institutions ... often lack the experience to manage risks, and in the face of stronger competition, institutions will tend to be pushed towards riskier investments @. Though, why banks that are stable without MNB competition become more prone to risk taking with it is so far unclear. MNB entry may destabilize domestic banks due to competitive pressures, due to poor capitalization of domestic banks, or due to Aderegulation euphoria@.

Obviously, MNB entry raises the number of banks, and thus the competitive pressures for domestic banks. To maintain their market share, domestic banks may extend credit to 
borrowers or projects of lesser quality, thus increasing automatically the default risk in their portfolios (Darity and Horn, 1988). While such a behavior is conceivable in the early stages of international financial competition, it appears unreasonable once MNBs have achieved a sizable market share. Domestic banks, which have less capital or know-how than MNBs should reduce their credit and risk exposure - as long as their net worth is above their safety threshold.

Domestic banks, which are plagued by low or even negative net worth may extend their loans to riskier market segments once international competition heats up, regardless of competitive pressures. Such banks simply stand to lose little or nothing in the case of a bank failure because they are de facto bankrupt. The mechanism that may push banks with relatively low net worth into seeking out high risk, high return projects is the same that induces lower lending by better capitalized banks, namely a decline in retained earnings. Banks= franchise value declines with lower profitability, and thus should lessen the expectations of poorly capitalized banks to improve their situation without increasing their portfolio risk.

Finally, financial instabilities could arise from Aderegulation euphoria@. That is, banks may become overly optimistic about borrower quality, and subsequently extend their loans to include less credit worthy projects. MNB entry is part of FL, as are the elimination of interest rate ceilings, the reduction of lending restrictions, capital account liberalization, and domestic deregulation. Previously credit constrained sectors may now receive funding because higher real interest rates promise more profits to banks. More credit might in turn increase investment, both for productive and speculative projects. These real and financial expansions should attract overseas investors, which may lead to an appreciation, attracting even more capital. However, 
rather than a stable equilibrium, changes in economic fundamentals may merely produce periods of tranquility (Minsky, 1986). The initial boom may already lay the foundation for later instabilities. For instance, internal liberalization may aid short-term speculative finance, thereby raising the chance of borrower default. Similarly, a continuously overvalued currency hurts exporters, and may lead to a deterioration in the current account balance. Hence, real and financial sectors may ultimately grow apart. Borrower default rise, and currency depreciation and bank instabilities follow suit.

The role of MNBs in a destabilizing cycle may be that it increases the optimism among lenders, and thereby fuels an unsustainable credit expansion. The presence of overseas capital may be seen by domestic banks as a Astamp of approvale for the economic success of an economy. In other words, domestic investors may interpret more financial service FDI as a signal of sound economic fundamentals, thereby inducing them to lend more than they otherwise would.

The entry of MNBs can impact the credit supply in either direction as more international financial competition may induce a credit contraction, and increase the propensity for banks to engage in more risky projects. The implications of this dual effect are that while credit contractions may dominate in the early stages of FL, credit expansion may become dominant over time as MNBs grow and as banks and regulators become more confident with the new situation.

The entry of MNBs can impact both credit supply and financial stability in either direction. On the one hand, domestic banks may want to reduce their risk exposure by lowering their loan exposure, on the other hand, domestic banks may want to raise their expected revenue streams by lending more for riskier activities. The implication of our discussion is that while 
credit contractions may dominate in the early stages of FL, credit expansion may become dominant over time as banks and regulators become more confident with the new situation.

\section{III.1 Empirical Analysis}

The figures in table 2 indicate that credit contractions continue after MNB entry. The measures used here are enterprise credit - the sum of credit to private and public enterprises - and total credit. After MNB entry credit growth relative to GDP tends to be higher, except for Latin America, where credit declines at about 5\%. Moreover, in the Middle East and Eastern Europe total credit relative to GDP is still shrinking after the entry of MNBs, at $-1.62 \%$ and $-0.62 \%$, respectively. Further, even though total credit is growing in Africa, it is one out of two areas, the other being Latin America, where enterprise credit is shrinking, while MNBs are present.

While the credit supply seems to be improving in the presence of MNBs, the issue remains whether MNB presence can be linked to the credit supply. In 24 out of 88 countries, total credit is positively correlated with MNB presence. However, in 19 out of 88 countries, the credit supply is negatively correlated with MNB presence. Hence, we cannot infer any conclusions from the simple descriptive statistics about the connection between MNB presence and credit supply.

Part of the reason for the conflicting evidence may be that while MNB presence may initially result in less credit supply, it may also induce riskier loans in later periods. Thus, we should be able to observe a growth in the likelihood of banking crises, the longer MNBs are present in less industrialized economies. The data set is therefore split, so that we can get a sense on the link between MNB presence and crises. A year is qualified as a crisis year if its banking 
system is showing either significant problems or experiences a crisis (Garcia, Lindgren and Saal, 1996). There are 95 different events that are classified as banking crises up to 1996, during the majority of which, 52, MNBs have been present. Thus, observations are classified as occurring when MNBs are present, or when MNBs are not present. Further, MNBs are considered present either if there is any MNB credit, or if MNBs have at least a $1 \%$, a $2 \%$, or a $3 \%$ credit market share. The chance of a crisis is then calculated for the first five years, the second five years, and any years beyond the first ten years of MNB presence. Table 4 shows that MNB presence is loosely connected with the occurrence of a crisis. While the probability of a bank crisis hovers around $4 \%$ for the first 5 years of MNB presence, it increases to $6 \%$ for the second 5 years, before it declines to $4-5 \%$ for the years after the first ten years. In other words, there is some reason to suspect that the presence of MNBs may have initially a stabilizing impact on domestic financial systems, while international financial competition may become destabilizing over time.

We can also find some support for MNB growth as part of a Aderegulation euphoria@. In particular, MNB presence grows above average in the year leading up to a crisis (table 5) ${ }^{4}$. While the growth rate of MNB loans is on average 32.46 percentage points below their mean during tranquil periods two years prior to a crisis, it is 40.41 percentage points higher one year prior to a crisis. Further, MNB credit market share grows above its tranquil period average in the year just before a crisis, which indicates that MNBs are expanding their loans faster than domestic

${ }^{4}$ The figures in table 5 are calculated by first defining the two years prior to a crisis year, the actual crisis year, and the two years after a crisis as crisis periods. Then, the average for the noncrisis periods is taken. Finally, the difference of a variable and its mean during non-crisis periods is calculated. The mean of this difference for the crisis periods is reported in table 5. 
banks.

The fact that MNBs are expanding their loans faster than domestic banks prior to a crisis may raise the overall default risk, thus increasing the chance of a crisis (Kaminsky and Reinhart, 1996; Demirgüc-Kunt and Detragiache, 1998). The main link between more credit and instability are overly optimistic expectations resulting in the expansion of credit to market segments of lower quality. Such optimistic expectations may be aided by a growing MNB presence, possibly because domestic lenders see the activities of MNBs as Astamp of approvale for the performance of the domestic economy. Thus, while MNBs may initially raise stability by inducing banks to reduce credit, they may also help to raise lenders= expectations and to foster imprudent lending practices.

\section{III.2 Regression Analysis}

So far, the figures indicate no clear link between MNBs and credit supply, while there is some indication that less industrialized economies may become more unstable the longer MNBs are present, and the more they grow. To investigate the impact of MNBs on credit supply and on stability, we use a credit supply function derived from a standard credit supply model under credit rationing (Greenwald and Stiglitz, 1990).The estimation equation, then, looks as follows:

$$
\begin{aligned}
& \frac{\text { EnterpriseCredit }}{G D P}_{i t}=a+b_{1} \frac{\text { BankCapital }}{G D P} \sqrt{i t}_{\downarrow}+b_{2} \frac{\text { Deposits }}{G D P} \sqrt{i t}_{\downarrow}+b_{3} \frac{G d p}{\text { Population }} V_{i t-1} \\
& +b_{4} \frac{\text { MNBCredit }}{G D P} \sqrt{i t}_{\downarrow}+b_{5} \frac{\text { MNBCredit }}{G D P} \sqrt{ }^{2}{ }_{i t-1}+b_{6} \frac{\text { EnterpriseCredit }}{G D P} V_{i t-1}+\mu_{i t}
\end{aligned}
$$

where Enterprise Credit is the credit supply to private and public firms, Bank Capital is the total bank capital, Deposits are all bank deposits, GDP is nominal GDP, Gdp is real GDP, Population 
is the current population, $M N B$ Credit is the credit lent out by all MNBs, and $\varepsilon$ is the error term.

As our argument pertains to commercial loans by domestic banks, our dependent variable is enterprise credit i.e., the sum of bank credit to private and public enterprises, relative to GDP. We include its lagged value as explanatory variable, which allows us to control for omitted variables. Later, we reestimate the regression using total credit as the dependent variable. As most credit is enterprise credit (table 3), the effect of international financial competition on enterprise credit may be large enough to have a significant impact on the total credit supply.

In its basic form, bank credit is supposed to depend on a bank=s capital, its deposit base, and on the performance of its borrowers in the previous period. Consequently, we expect that the credit supply depends positively on changes in bank capital and deposits, and on increases in real per capita GDP. Due to the fact that the data set comprises aggregate data, the deposit variable also controls for changes in a country $=\mathrm{s}$ monetary stance, and real per capita GDP growth accounts for the performance of each economy=s real sector. Further, to model the ambiguous effect that MNB presence may have on credit supply, we include both a linear and a quadratic term for MNB presence. With a growing MNB presence, domestic lenders= expectations may become more optimistic as greater MNB activity may be perceived as Astamp of approvale for the performance of the local economy. Thus, we would expect MNB presence to affect credit supply negatively when MNBs are small, and increasingly more positively as MNBs grow.

To analyze the impact of MNB presence on credit supply in less industrialized 
economies, we begin by estimating the regression using least squares with dummy variables to control for country fixed effects. Since deposits may be endogenously related to the credit supply, we estimate the regression by using two stage least squares, where the lagged value of deposits serves as instrument. The results in regression (1) in table 6 show that all variables have either the expected sign or are insignificant. Most importantly for our purposes, the MNB variables are both significant with the right sign, suggesting that MNBs lower the supply of credit as long as they are small, and eventually have a positive influence on the supply of credit to enterprises. Thus, enterprise credit reaches its lowest point when MNB credit is equal to $15.9 \%$ of GDP. Looking at it differently, if MNB presence is at its average of 3.25\% of GDP (table 3 ) and increases by 2 percentage points relative to GDP, the supply of enterprise credit declines by 1.01 percentage points relative to GDP. Only if MNB presence grows beyond $15.9 \%$ of GDP, which is the case for 10 countries out of 112 , does its impact on the supply of enterprise credit turn positive.

Recently, a number of multilateral agreements have made it easier for MNBs to expand their activities into less industrialized economies. For instance, the completion of the Uruguay round on the General Agreement on Tariffs and Trade (GATT) in 1994, and the subsequent ratification of the GATS in 1997 lower barriers to MNB entry. To account for such global changes, we add time fixed effects, with the results in regression (2) of table 6 showing our estimates unchanged, both with respect to significance and size of the explanatory variables.

Aside from changes over time that affect all economies, countries may undergo shifts in their policies regarding MNBs at times separate from changes in other economies. Such individual 
policy changes, often in the form of more financial liberalization, are not captured by time fixed effects, and may only be partially accounted for by the inclusion of deposits and real per capita GDP growth in the regression. Hence, we add a time trend for each country individually, starting with the year when MNB credit is first reported. As such a trend measures a country=s response to international financial competition, and presumably other related liberalization measures, it seems only reasonable to assume that as institutions become more adept to the new, more competitive environment, their responses become gradually less pronounced. In other words, such a trend may not be in a linear form, but rather a logged form. Adding this logged time trend to the previous regressions, provides us with regression (3) of table 6 . The regression results show, that the previous estimates are robust, still indicating a U-shaped response to MNB loans, with the strongest negative impact when MNB credit amounts to 18.1\% of GDP in the previous period.

Another way of test the robustness of the results is to reestimate the equation employing a logarithmic specification. Obviously, the squared term of international financial competition disappears in this specification, which shows again an overall negative response in enterprise credit to MNB credit. Also, all other results reappear in this specification. However, using Theil=s (1972) residual variance criterion on the larger residual sum of squares for the logarithmic model and the smaller residual sum of squares for the levels model, we obtain a test value of 2.08 , which is $\mathrm{F}$ distributed with 210 degrees of freedom in both the numerator and the denominator suggesting that the levels model is the more appropriate specification at the $1 \%$ level.

Given that there is a negative effect of MNB loans on the supply of enterprise credit, the 
issue arises whether this translates into an overall decline of credit. Similar to our proceeding with respect to enterprise credit, we estimate the impact of MNB presence on the supply of total credit in regressions (1) through (4) in table 7. Our results show only a negative response to MNB credit, indicating that for each increase of MNB credit relative to GDP in the previous period to the tune of one standard deviation results in a decline of total credit by 3.13 percentage points relative to GDP, when country and time fixed effects as well as country specific trends are accounted for ${ }^{5}$. Put differently, the negative response in enterprise credit to MNB credit seems to be strong enough to lower total credit, while the positive impact of larger MNB market shares on the supply of enterprise credit does not appear to translate into more total credit.

Considering that in the majority of economies the impact of MNB loans has been to lower the amount of either enterprise credit or total credit, it is hard to see how international financial competition could result directly in more fragile banking systems. On the contrary, because of their overall negative impact on the credit exposure of domestic banks, MNBs may help to stabilize the local banking systems, at least so far. The fact that we observe an increasing likelihood of banking crises the longer MNBs are present in less industrialized economies, may therefore be simply correlated to other macro economic trends, such as unsustainable overvaluations, large international short-term debt positions, or persistent current account deficits.

Aside from helping to stabilize domestic banks systems, there may be other implications

${ }^{5}$ Calculating Theil=s residual variance criterion to compare the two specifications we obtain an Fdistributed test statistic of 6.18 with 392 d.f. in the numerator and 401 d.f. in the denominator. 
of a less credit. For instance, the supply of credit may have a positive impact on growth in less industrialized economies (Calvo and Corricelli, 1993; Odedokun, 1996), which suggests that a growing MNB presence in most less industrialized economies may put a damper on growth. This possible negative impact on growth may be attributable to the negative impact of declining credit on business investment, which depends positively on a sufficient supply of bank credit.

The question is whether all firms are likely to experience finance constraints to the same degree. Domestic banks can reduce their loans to all their borrowers at the same rate, or they can reduce their loans to some more than others. Given that loans to some borrowers are less costly, and often also less risky, it is likely that domestic banks will reduce these loans to a lesser degree than more costly loans. Arguably, loans to smaller borrowers are more costly and often riskier, when compared with loans to MNCs or large domestic corporations. Hence, SMEs, or start-up companies are more likely to experience finance constraints than larger, more established firms. This seems to have been the case in Hungary, for example, where by 1995, most domestic banks have been foreign owned, and where finance constraints for SMEs and start-up companies have been recognized recently (Anderson and Kegels, 1998; Abel, Siklos, and Szekely, 1998).

\section{Conclusion}

In this paper, we study the impact of MNB presence on credit supply and financial stability in less industrialized economies. We find that domestic banks lower their total credit exposure by reducing their commercial loans in response to increased competition, particularly in

serving MNCs, domestic corporations, or high net worth individuals. The limited evidence that is

Thus, the levels specification is again the more appropriate one at the $1 \%$ level. 
available suggests that SMEs and start-up companies may be particularly affected by growing finance constraints in the face of a larger MNB presence. Further, as banks reduce their credit exposure to lower their risk exposure in the face of more international financial competition, they are also increasing the stability of the domestic banking system.

As the overall impact of MNB presence seems to be to lower enterprise credit and total credit, other reasons to permit MNB entry need to be compelling enough to compensate for its drawbacks. For instance, earlier research indicates that MNBs follow MNCs into less industrialized economies. It is therefore conceivable, that MNBs aid MNC operations, and that they lead to more FDI growth in the long run. As much as MNCs are desirable partners in economic development this connection between MNBs and MNCs should be weighed against the possibly dampening effect on business investment. Further, in the wake of the recent financial crises, FDI flows, and among them FDI in financial services, may be considered more stable than short term portfolio flows. As far as less industrialized economies depend on international capital for their development, MNB entry may hence offer a desirable alternative to portfolio investment.

Before weighing different policy options, one aspect should be kept in mind. In some cases, the growth rate of MNBs has been so rapid that within a short time span MNBs have gained a sizable market share, and sometimes even a majority share of the domestic banking sector. Considering that MNB entry is not only a matter of domestic banking development, but also of international trade, implementing financial policy measures, which may affect MNBs, may be complicated by bilateral or multilateral agreements, such as GATS, especially in financial 
markets where MNBs play a major role. As the latest multilateral agreements, in particular the GATS, have meant greater mobility for MNBs, their presence is likely to grow further in the near future, which makes especially smaller economies more vulnerable to adverse decisions in trade disputes if they want to implement restrictions on MNB activities (Brown, 1999).

While there may be compelling reasons to attract MNBs into less industrialized economies, policymakers may want to consider regulatory actions that help to lower the adverse effects of MNB entry. For instance, recent studies on MNB presence suggest that MNBs, which have entered joint ventures or strategic partnerships with domestic banks are more likely to serve typically finance constrained market segments, such as start-up companies or SMEs. Hence, encouraging or requiring such partnerships - as far as this can be achieved in accordance with international agreements - may help to lower the drawbacks of MNB entry. 
TABLE 1

SUMMARY STATISTICS FOR MULTINATIONAL BANKS BY YEAR AND GEOGRAPHICAL AREA

\begin{tabular}{|c|c|c|c|c|c|c|c|c|c|c|}
\hline \multirow[t]{2}{*}{ Year } & \multicolumn{5}{|c|}{ Total MNB Lending (Mn. US\$) } & \multicolumn{5}{|c|}{ Net Imports (MNB Loans- MNB Deposits) (Mn. US\$) } \\
\hline & $\begin{array}{l}\text { Eastern } \\
\text { Europe }\end{array}$ & $\begin{array}{l}\text { Latin } \\
\text { America }\end{array}$ & $\begin{array}{l}\text { Middle } \\
\text { East }\end{array}$ & Africa & Asia & $\begin{array}{l}\text { Eastern } \\
\text { Europe }\end{array}$ & $\begin{array}{l}\text { Latin } \\
\text { America }\end{array}$ & $\begin{array}{l}\text { Middle } \\
\text { East }\end{array}$ & Africa & Asia \\
\hline 1985 & 77 & 9773 & 2608 & 3499 & 15130 & 0 & 2332 & -15 & 298 & 6022 \\
\hline 1986 & 275 & 12728 & 2960 & 3397 & 14454 & 72 & 2199 & -32 & -4 & 3691 \\
\hline 1987 & 367 & 14308 & 3152 & 3696 & 17308 & 32 & 2474 & -109 & 71 & 6516 \\
\hline 1988 & 365 & 14358 & 3345 & 4478 & 17454 & 18 & -807 & -58 & 20 & 6164 \\
\hline 1989 & 379 & 13420 & 1582 & 3852 & 23332 & 69 & 2028 & 58 & 18 & 6910 \\
\hline 1990 & 420 & 15312 & 1908 & 4525 & 27472 & 55 & 2302 & 227 & -67 & 9345 \\
\hline 1991 & 708 & 16668 & 1932 & 3953 & 30461 & -28 & 3160 & 52 & -16 & 10570 \\
\hline 1992 & 518 & 21385 & 2246 & 4054 & 36395 & 156 & 5700 & 106 & -131 & 13327 \\
\hline 1993 & 1358 & 24908 & 4368 & 4732 & 45417 & 526 & 6128 & -133 & -375 & 14822 \\
\hline 1994 & 7818 & 30357 & 4852 & 6575 & 51836 & 3457 & 7804 & -6 & -899 & 17227 \\
\hline 1995 & 8295 & 44276 & 5393 & 8180 & 56517 & 2901 & 10649 & 508 & -91 & 18446 \\
\hline 1996 & 15849 & 64089 & 5615 & 6862 & 64949 & 5538 & 16245 & 568 & 714 & 21158 \\
\hline 1997 & 24499 & 123040 & 6836 & 6988 & 73260 & 7562 & 24530 & -1505 & 502 & 16093 \\
\hline $\begin{array}{l}1997 \text { MNB } \\
\text { Market Share }\end{array}$ & 14.27 & 16.93 & 0.41 & 9.13 & 4.63 & - & - & - & - & - \\
\hline
\end{tabular}

Sources: BIS, Consolidated International Banking Statistics; IMF, International Financial Statistics. 
TABLE 2

MULTINATIONAL AND INTERNATIONAL BANKING STATISTICS BY GEOGRAPHICAL AREA FROM 1985 TO 1997

\begin{tabular}{|c|c|c|c|c|c|c|c|c|c|c|}
\hline Variable & \multicolumn{2}{|c|}{ Eastern Europe } & \multicolumn{2}{|c|}{ Latin America } & \multicolumn{2}{|c|}{ Middle East } & \multicolumn{2}{|c|}{ Asia } & \multicolumn{2}{|c|}{ Africa } \\
\hline Average Growth of MNBs $(\%)^{\mathrm{ac}}$ & \multicolumn{2}{|c|}{739.5} & \multicolumn{2}{|c|}{133.38} & \multicolumn{2}{|c|}{34.75} & \multicolumn{2}{|c|}{31.16} & \multicolumn{2}{|c|}{140.26} \\
\hline Average Credit Market Share of MNBs $(\%)^{\mathrm{b}}$ & \multicolumn{2}{|c|}{2.11} & \multicolumn{2}{|c|}{8.02} & \multicolumn{2}{|c|}{1.6} & \multicolumn{2}{|c|}{2.96} & \multicolumn{2}{|c|}{2.79} \\
\hline $\begin{array}{l}\text { Average Deposit Market Share of MNBs } \\
(\%)^{b}\end{array}$ & \multicolumn{2}{|c|}{2.41} & \multicolumn{2}{|c|}{9.26} & \multicolumn{2}{|c|}{2.81} & \multicolumn{2}{|c|}{3.4} & \multicolumn{2}{|c|}{7.52} \\
\hline $\begin{array}{l}\text { Average Growth of International Bank Loans } \\
(\%)^{\mathrm{b}}\end{array}$ & \multicolumn{2}{|c|}{10.65} & \multicolumn{2}{|c|}{7.44} & \multicolumn{2}{|c|}{17.17} & \multicolumn{2}{|c|}{16.74} & \multicolumn{2}{|c|}{2.15} \\
\hline \multirow{2}{*}{$\begin{array}{l}\text { Average Ratio of MNB Credit to } \\
\text { International Bank Credit }(\%)^{\mathrm{b}}\end{array}$} & \multicolumn{2}{|c|}{9.15} & \multicolumn{2}{|c|}{21.6} & \multicolumn{2}{|c|}{6.5} & \multicolumn{2}{|c|}{12.14} & \multicolumn{2}{|c|}{17.65} \\
\hline & $\begin{array}{l}\text { Without } \\
\text { MNBs }\end{array}$ & $\begin{array}{l}\text { With } \\
\text { MNBs }\end{array}$ & $\begin{array}{l}\text { Without } \\
\text { MNBs }\end{array}$ & $\begin{array}{l}\text { With } \\
\text { MNBs }\end{array}$ & $\begin{array}{l}\text { Without } \\
\text { MNBs }\end{array}$ & $\begin{array}{l}\text { With } \\
\text { MNBs }\end{array}$ & $\begin{array}{l}\text { Without } \\
\text { MNBs }\end{array}$ & $\begin{array}{l}\text { With } \\
\text { MNBs }\end{array}$ & $\begin{array}{l}\text { Without } \\
\text { MNBs }\end{array}$ & $\begin{array}{l}\text { With } \\
\text { MNBs }\end{array}$ \\
\hline $\begin{array}{l}\text { Average Growth of Enterprise Credit/GDP } \\
(\%)^{\mathrm{a}}\end{array}$ & -4.79 & -0.85 & -3.03 & -3.8 & -0.76 & 0.69 & -0.16 & 4.52 & 0.2 & -1.14 \\
\hline Average Growth of Total Credit/GDP $(\%)^{\mathrm{a}}$ & -2.28 & -0.62 & 1.57 & -5.05 & -2.18 & -1.67 & 0.16 & 2.51 & -0.81 & 0.02 \\
\hline
\end{tabular}

Sources: BIS, Consolidated International Banking Statistics; IMF, International Financial Statistics.

Notes: ${ }^{a}$ all averages are GDP weighted averages.

${ }^{\mathrm{b}}$ averages calculated only if MNB lending is present in the same period.

${ }^{\mathrm{c}} \mathrm{MNB}$ loan growth rates are calculated after loans are re-converted into domestic currency. 
TABLE 3

SUMMARY STATISTICS

\begin{tabular}{lcccccc}
\hline & & & & & \\
& All & Eastern & Middle & Latin & Asia & Africa \\
& Countries & Europe & East & America & & \\
_(Gdp/Population $)_{t}$ & 1.639 & 0.103 & 0.211 & 4.435 & 3.387 & -0.292 \\
& $(21.856)$ & $(13.121)$ & $(20.933)$ & $(5.660)$ & $(5.660)$ & $(12.249)$ \\
$(\text { MNB Credit/GDP })_{t}$ & 3.248 & 1.166 & 1.863 & 5.308 & 2.168 & 2.41 \\
& $(5.11)$ & $(1.883)$ & $(2.920)$ & $(6.423)$ & $(1.881)$ & $(4.957)$ \\
$($ Bank Capital/GDP) & 4.894 & 4.811 & 7.508 & 5.116 & 5.894 & 2.547 \\
& $(4.250)$ & $(3.925)$ & $(6.130)$ & $(4.169)$ & $(3.992)$ & $(3.149)$ \\
$(\text { Deposits/GDP })_{t}$ & 29.442 & 25.442 & 53.548 & 33.221 & 34.354 & 20.755 \\
& $(19.402)$ & $(15.875)$ & $(24.515)$ & $(17.777)$ & $(16.187)$ & $(13.160)$ \\
& 41.907 & 43.409 & 64.892 & 51.480 & 44.776 & 28.795 \\
$($ Total Credit/GDP) & $(36.390)$ & $(26.064)$ & $(36.471)$ & $(50.343)$ & $(25.929)$ & $(22.904)$ \\
& 25.096 & 28.030 & 30.876 & 34.136 & 29.406 & 12.874 \\
& $(18.528)$ & $(20.648)$ & $(15.238)$ & $(16.513)$ & $(24.295)$ & $(8.001)$ \\
& & & & & & \\
\hline
\end{tabular}

Note: All figures in percent. Standard deviation in parentheses. 
MNBs have less

than...
MNBs Present

MNBs have...

First 5 Years

Second 5 Years with...

with..

Third 5 Years and Beyond with...

\begin{tabular}{|c|c|c|c|c|}
\hline \multirow[b]{2}{*}{0.056} & \multicolumn{3}{|c|}{...no minimum credit market share. } & \multirow[b]{2}{*}{0.032} \\
\hline & 0.045 & 0.037 & 0.061 & \\
\hline \multicolumn{5}{|c|}{...at least $1 \%$ credit market share. } \\
\hline 0.059 & 0.051 & 0.043 & 0.058 & 0.051 \\
\hline \multicolumn{5}{|c|}{...at least $2 \%$ credit market share. } \\
\hline 0.058 & 0.05 & 0.04 & 0.062 & 0.046 \\
\hline \multicolumn{5}{|c|}{...at least $3 \%$ credit market share. } \\
\hline 0.06 & 0.049 & 0.042 & 0.054 & 0.051 \\
\hline
\end{tabular}

Sources: BIS, Consolidated International Banking Statistics; IMF, International Financial Statistics TABLE 5

MNB GROWTH AND MNB MARKET SHARE IN YEARS PRIOR TO BANKING CRISES (DEVIATION FROM NON-CRISIS PERIODS)

\begin{tabular}{lll} 
& \multicolumn{2}{l}{ Deviation from average during non-crisis times } \\
& MNB Market Share Growth & MNB Lending Growth \\
2 years prior to crisis year & -2.37 & -32.46 \\
1 year prior to crisis year & 0.95 & 40.41
\end{tabular}

Sources: BIS, Consolidated International Banking Statistics; IMF, International Financial 
TABLE 6

ENTERPRISE CREDIT SUPPLY WITH MNB PRESENCE

Dependent Variable

\begin{tabular}{|c|c|c|c|c|}
\hline & $\begin{array}{c}(1) \\
\text { LSDV }\end{array}$ & $\begin{array}{c}(2) \\
\text { LSDV }\end{array}$ & $\begin{array}{c}(3) \\
\text { LSDV }\end{array}$ & $\begin{array}{c}(4) \\
\text { LSDV }\end{array}$ \\
\hline$\left(\text { Bank Capital }_{\mathrm{i}} / \mathrm{GDP}\right)_{\mathrm{t}}$ & $\begin{array}{c}1.6666 * * * \\
(0.1925)\end{array}$ & $\begin{array}{c}1.6536 * * * \\
(0.1930)\end{array}$ & $\begin{array}{c}1.7230 * * * \\
(0.2007)\end{array}$ & $\begin{array}{c}0.2251 * * * \\
(0.0440)\end{array}$ \\
\hline$(\text { Deposits/GDP })_{t}$ & $\begin{array}{c}0.0185 \\
(0.1165)\end{array}$ & $\begin{array}{c}0.0271 \\
(0.1170)\end{array}$ & $\begin{array}{c}0.0022 \\
(0.1254)\end{array}$ & $\begin{array}{l}-0.3083 \\
(0.2607)\end{array}$ \\
\hline$(\mathrm{Gdp} / \text { Population })_{t-1}$ & $\begin{array}{c}0.1509 * * * \\
(0.0225)\end{array}$ & $\begin{array}{c}0.1547 * * * \\
(0.0239)\end{array}$ & $\begin{array}{c}0.1665 * * * \\
(0.0246)\end{array}$ & $\begin{array}{c}0.2786 * * * \\
(0.0871)\end{array}$ \\
\hline$(\text { Enterprise Credit/GDP })_{\mathrm{t}-1}$ & $\begin{array}{c}0.5406 * * * \\
(0.0474)\end{array}$ & $\begin{array}{c}0.5479 * * * \\
(0.0483)\end{array}$ & $\begin{array}{c}0.5535 * * * \\
(0.0494)\end{array}$ & $\begin{array}{c}0.8717 * * * \\
(0.1221)\end{array}$ \\
\hline$(\mathrm{MNB} \text { Credit/GDP })_{\mathrm{t}-1}$ & $\begin{array}{c}-0.5406 * * \\
(0.2212)\end{array}$ & $\begin{array}{c}-0.5663 * * \\
(0.2235)\end{array}$ & $\begin{array}{c}-0.5703 * * \\
(0.2345)\end{array}$ & $\begin{array}{c}-0.0268 * \\
(0.0154)\end{array}$ \\
\hline$(\mathrm{MNB} \text { Credit/GDP })_{\mathrm{t}-1}{ }^{2}$ & $\begin{array}{l}0.0170 * \\
(0.0091)\end{array}$ & $\begin{array}{l}0.0167 * \\
(0.0092)\end{array}$ & $\begin{array}{l}0.0158 * \\
(0.0094)\end{array}$ & N/A \\
\hline Logged Time Trend & N/A & N/A & $\begin{array}{c}3.9589 \\
(5.8842)\end{array}$ & $\begin{array}{c}0.0899 \\
(0.2491)\end{array}$ \\
\hline Constant & $\begin{array}{c}-41.5759 * * * \\
(7.1684)\end{array}$ & $\begin{array}{c}-42.9744 * * * \\
(7.7939)\end{array}$ & $\begin{array}{c}-34.4382 * * \\
(18.7875)\end{array}$ & $\begin{array}{l}-0.1585 \\
(0.3966)\end{array}$ \\
\hline Country Dummies & Yes & Yes & Yes & Yes \\
\hline Year Dummies & No & Yes & Yes & Yes \\
\hline No. of Observations & 275 & 275 & 260 & 259 \\
\hline Adj. R-squared & 0.9447 & 0.9447 & 0.9452 & 0.9139 \\
\hline F-statistic & 124.15 & 96.31 & 319.06 & 1508.83 \\
\hline
\end{tabular}

Note: Standard errors in parentheses below coefficients. * denotes significance at the $10 \%$ level, $* *$ significance at the $5 \%$ level, and *** significance at the $1 \%$ level. 
TABLE 7

TOTAL CREDIT SUPPLY WITH MNB PRESENCE

\begin{tabular}{|c|c|c|c|c|}
\hline \multirow[t]{3}{*}{ Dependent Variable } & \multicolumn{3}{|c|}{$(\text { Total Credit/GDP })_{t}$} & \multirow{3}{*}{$\begin{array}{l}\text { Memorandum Item: } \\
\text { Logarithmic Specification } \\
\text { (4) } \\
\text { LSDV }\end{array}$} \\
\hline & (1) & (2) & (3) & \\
\hline & LSDV & LSDV & LSDV & \\
\hline$(\text { Bank Capital/GDP })_{t}$ & $\begin{array}{c}2.2208 * * * \\
(0.2569)\end{array}$ & $\begin{array}{c}2.2631 * * * \\
(0.2405)\end{array}$ & $\begin{array}{c}2.3105^{* * * *} \\
(0.1748)\end{array}$ & $\begin{array}{c}0.1544 * * * \\
(0.0233)\end{array}$ \\
\hline$(\text { Deposits/GDP })_{t}$ & $\begin{array}{c}-0.5493 * * * \\
(0.1601)\end{array}$ & $\begin{array}{c}-0.3394 * * \\
(0.1615)\end{array}$ & $\begin{array}{c}-0.2946^{*} \\
(0.1748)\end{array}$ & $\begin{array}{c}0.0542 \\
(0.0849)\end{array}$ \\
\hline$(\mathrm{Gdp} / \text { Population })_{t-1}$ & $\begin{array}{c}0.1151 * * * \\
(0.0306)\end{array}$ & $\begin{array}{c}0.1084 * * * \\
(0.0284)\end{array}$ & $\begin{array}{c}0.1099 * * * \\
(0.0307)\end{array}$ & $\begin{array}{c}0.1767 * * * \\
(0.0543)\end{array}$ \\
\hline$(\text { Total Credit/GDP })_{t-1}$ & $\begin{array}{c}0.6803 * * * \\
(0.0426)\end{array}$ & $\begin{array}{c}0.6227 * * * \\
(0.0435)\end{array}$ & $\begin{array}{c}0.5981 * * * \\
(0.0457)\end{array}$ & $\begin{array}{c}0.6512 * * * \\
(0.0403)\end{array}$ \\
\hline$(\mathrm{MNB} \text { Credit/GDP })_{\mathrm{t}-1}$ & $\begin{array}{c}-0.7003 * * \\
(0.3491)\end{array}$ & $\begin{array}{c}-0.7444 * * \\
(0.3221)\end{array}$ & $\begin{array}{c}-0.6131 * \\
(0.3379)\end{array}$ & $\begin{array}{c}-0.0293 * * * \\
(0.0097)\end{array}$ \\
\hline$(\mathrm{MNB} \text { Credit/GDP })_{\mathrm{t}-1}^{2}$ & $\begin{array}{l}-0.0147 \\
(0.0120)\end{array}$ & $\begin{array}{c}0.0156 \\
(0.0111)\end{array}$ & $\begin{array}{c}0.0126 \\
(0.0126)\end{array}$ & N/A \\
\hline Logged Time Trend & N/A & N/A & $\begin{array}{c}-13.1471 * * \\
(5.3887)\end{array}$ & $\begin{array}{l}-0.2519 \\
(0.1027)\end{array}$ \\
\hline Constant & $\begin{array}{c}-10.6046 \\
(7.2558)\end{array}$ & $\begin{array}{c}-39.4429 * * * \\
(12.0485)\end{array}$ & $\begin{array}{c}76.5135 \\
(19.5644)\end{array}$ & $\begin{array}{c}0.4112 * * \\
(0.1958)\end{array}$ \\
\hline Country Dummies & Yes & Yes & Yes & Yes \\
\hline Year Dummies & No & Yes & Yes & Yes \\
\hline No. of Observations & 515 & 515 & 478 & 467 \\
\hline Adj. R-squared & 0.9042 & 0.9193 & 0.9227 & 0.9253 \\
\hline F-statistic & 77.77 & 255.47 & 75.96 & 3193.5 \\
\hline
\end{tabular}

Note: Standard errors in parentheses below coefficients. * denotes significance at the $10 \%$ level, $* *$ significance at the $5 \%$ level, and $* * *$ significance at the $1 \%$ level. 


\section{Appendix:}

\section{A. List of Countries}

\begin{tabular}{|c|c|c|c|}
\hline Country & $\begin{array}{l}\text { MNB Loans by } \\
\text { Mid-1998 }\end{array}$ & $\begin{array}{l}\text { Banking Crisis From } \\
1985 \text { and } 1996\end{array}$ & $\begin{array}{l}\text { Market Share of MNBs when } \\
\text { Banking Crisis Occurred }\end{array}$ \\
\hline \multicolumn{4}{|l|}{ Eastern Europe } \\
\hline Bulgaria & 23 & 1995 & \\
\hline Czech Republic & 5103 & 1994 & 4.82 \\
\hline Slovakia & 599 & 1991 & \\
\hline Hungary & 4363 & 1987 & \\
\hline Poland & 7512 & 1991 & 8.05 \\
\hline Romania & 286 & 1990 & \\
\hline Armenia & 511 & 1994 & \\
\hline Estonia & 50 & 1992 & \\
\hline Kazakhstan & 64 & 1991 & \\
\hline Latvia & 12 & 1995 & \\
\hline Russia & 2356 & 1992 & \\
\hline Ukraine & 21 & 1994 & \\
\hline Uzbekistan & 8 & 1993 & \\
\hline \multicolumn{4}{|l|}{ Latin America } \\
\hline Argentina & 20327 & $1989 ; 1995$ & n.a.; 5.42 \\
\hline Belize & 65 & & \\
\hline Bolivia & 90 & 1986, 1994 & n.a.; 0.17 \\
\hline Brazil & 61965 & 1994 & 5.26 \\
\hline Chile & 12120 & & \\
\hline Colombia & 5140 & & \\
\hline Costa Rica & 81 & 1994 & 0.53 \\
\hline Dominica & 56 & & \\
\hline Dominican Rep. & 298 & 1992 & 12.79 \\
\hline Ecuador & 185 & 1995 & 2.07 \\
\hline El Salvador & 264 & 1989 & 0.55 \\
\hline Grenada & 42 & & \\
\hline Guatemala & 41 & & \\
\hline Guyana & 31 & 1993 & \\
\hline Haiti & 88 & 1994 & 21.63 \\
\hline Honduras & 33 & & \\
\hline Jamaica & 1442 & 1994 & 96.11 \\
\hline Mexico & 18889 & 1994 & 1.81 \\
\hline Paraguay & 611 & 1995 & 15.08 \\
\hline Peru & 1268 & & \\
\hline St. Lucia & 178 & & \\
\hline St. Vincent & 53 & 1994 & 34.78 \\
\hline Suriname & 35 & & 2.03 \\
\hline
\end{tabular}




\begin{tabular}{|c|c|c|c|}
\hline Country & $\begin{array}{l}\text { MNB Loans by } \\
\text { Mid-1998 }\end{array}$ & $\begin{array}{l}\text { Banking Crisis From } \\
1985 \text { and } 1996\end{array}$ & $\begin{array}{l}\text { Market Share of MNBs when } \\
\text { Banking Crisis Occurred }\end{array}$ \\
\hline Trinidad/Tobago & 770 & & \\
\hline Turks/Caicos & 35 & & \\
\hline Uruguay & 1434 & & \\
\hline Venezuela & 6411 & 1994 & 1.93 \\
\hline \multicolumn{4}{|l|}{ Middle East } \\
\hline Egypt & 919 & 1994 & 0.23 \\
\hline Iran & 3 & & \\
\hline Israel & 4 & & \\
\hline Inrdan & 95 & 1989 & 0.56 \\
\hline Oman & 532 & & \\
\hline Qatar & 116 & & \\
\hline Saudi Arabia & 29 & & \\
\hline United Arab Emirates & 4988 & & \\
\hline Yemen & 50 & & \\
\hline \multicolumn{4}{|l|}{ Africa } \\
\hline Algeria & 1083 & 1990 & 0.75 \\
\hline Angola & 546 & 1991 & \\
\hline Benin & 40 & 1988 & 1.05 \\
\hline Botswana & 8 & 1994 & \\
\hline Burkina Faso & 25 & 1988 & \\
\hline Burundi & 18 & 1994 & 0.53 \\
\hline Cameroon & 101 & 1989,1996 & $1.91 ; 12.08$ \\
\hline Cape Verde & 1 & 1995 & \\
\hline Chad & 3 & 1992 & \\
\hline Comoros & 1 & & \\
\hline Congo & 42 & 1994 & 0.32 \\
\hline Congo, Dem. Rep. & 46 & & 3.73 \\
\hline Ivory Coast & 335 & 1988 & 2.29 \\
\hline Djibouti & 43 & 1991 & \\
\hline Ethiopia & 47 & 1994 & \\
\hline Gabon & 135 & 1995 & 4.97 \\
\hline Gambia & 6 & 1985 & \\
\hline Ghana & 395 & & \\
\hline Guinea & 63 & & \\
\hline Kenya & 267 & 1993 & 1554 \\
\hline Lesotho & 107 & 1988 & 15 \\
\hline Madagascar & 82 & 1988 & \\
\hline Malawi & 3 & & \\
\hline Mali & 27 & 1987 & \\
\hline Mauritania & 36 & 1991 & \\
\hline Mauritius & 133 & 1996 & \\
\hline Morocco & 1202 & & \\
\hline
\end{tabular}




\begin{tabular}{|c|c|c|c|}
\hline Country & $\begin{array}{l}\text { MNB Loans by } \\
\text { Mid-1998 }\end{array}$ & $\begin{array}{l}\text { Banking Crisis From } \\
1985 \text { and } 1996\end{array}$ & $\begin{array}{l}\text { Market Share of MNBs when } \\
\text { Banking Crisis Occurred }\end{array}$ \\
\hline Mozambique & 8 & 1988,1994 & $0.49 ;$ n.a. \\
\hline Namibia & 6 & & \\
\hline Niger & 11 & & \\
\hline Nigeria & 329 & 1991 & 0.54 \\
\hline Rwanda & 7 & 1991 & 0.77 \\
\hline Senegal & 159 & & \\
\hline Somalia & 2 & 1990 & \\
\hline South Africa & 3573 & 1985,1989 & 1.21 \\
\hline Sudan & 26 & & \\
\hline Swaziland & 3 & 1995 & \\
\hline Tanzania & 27 & 1988 & 0.63 \\
\hline Togo & 7 & 1989 & \\
\hline Tunisia & 428 & 1991 & 0.50 \\
\hline Uganda & 4 & 1990 & \\
\hline Zambia & 73 & 1994 & \\
\hline Zimbabwe & 255 & 1995 & 1.32 \\
\hline \multicolumn{4}{|l|}{ Asia } \\
\hline Bangladesh & 120 & 1987 & \\
\hline Brunei & 839 & 1986 & \\
\hline China & 1196 & & \\
\hline Fiji & 55 & 1995 & \\
\hline French Polynesia & 439 & & \\
\hline India & 9642 & 1991 & 4.44 \\
\hline Indonesia & 2327 & 1992 & 2.79 \\
\hline South Korea & 10399 & 1986 & 5.76 \\
\hline Macao & 98 & & \\
\hline Malaysia & 5413 & 1985 & 9.15 \\
\hline Nepal & 27 & & \\
\hline New Caledonia & 445 & & \\
\hline Pakistan & 2723 & & \\
\hline Papua New Guinea & 62 & 1989 & \\
\hline Philippines & 3381 & & \\
\hline Sri Lanka & 156 & 1992 & 2.14 \\
\hline Taiwan & 11999 & & \\
\hline Thailand & 7296 & & \\
\hline US Pacific Islands & 95 & & \\
\hline Vietnam & 384 & & \\
\hline
\end{tabular}

Sources: BIS, Consolidated International Banking Statistics; IMF, International Financial Statistics; Lindgren, Garcia and Saal, 1996. 


\section{B. References:}

Aliber, Robert, 1984, International Banking: A Survey, Journal of Money, Credit and Banking, November: 661-712.

Balino, Tomas and V. Sundararajan, 1991, Banking Crises: Cases and Issues, Washington DC: International Monetary Fund.

Balino, Tomas, 1991, The Argentine Banking Crisis of 1980, in T. Balino and V. Sundararajan, eds., Banking Crises: Cases and Issues, Washington DC: International Monetary Fund.

Ball, Clifford and Adrian Tschoegl, 1982, The Decision to Establish a Foreign Branch or Subsidiary: A Speculation of Binary Classification Procedures, Journal of Financial and Quantitative Analysis, September:411-424.

Bank for International Settlements (BIS), 1997, Financial Stability in Emerging Market Economies, Report of the Working Party on Financial Stability in Emerging Market Economies, Basle: Bank for International Settlements.

Bank for International Settlements, 1997, Financial Stability in Emerging Market Economies, Report of the Working Party on Financial Stability in Emerging Market Economies, Basle: Bank for International Settlements.

Bown, Chad P., 1999, The Economics of Trade Disputes, the GATT=s Article XXIII and the WTO $=$ s Dispute Settlement Understanding, unpublished manuscript, Brandeis University.

Brainard, Lawrence J., 1990, Capital Markets in Korea and Taiwan: Emerging Opportunities for Foreign Banks, Journal of Asian Economics 1, No. 1: 173-177, 1990.

Business Week, 1983, How Foreign Banks Still Get Rich in Brazil, August 22, 1983.

Claessens, Stijn, A. Demirgüc-Kunt, and H, Huizinga, 1998, How Does Foreign Entry Affect the Domestic Banking Market?, Policy Research Working Paper \#1918, Washington DC: World Bank.

Cypher, James, 1996, Mexico: Financial Fragility or Structural Crisis?, Journal of Economic Issues 30, 2: 451-461.

Darity, William, Jr. and Bobbie L. Horn, 1988, The Loan Pushers: The Role of Commercial Banks in the International Debt Crisis, Cambridge, MA: Harper and Row, Ballinger. 
Demirgüc-Kunt, Asli and Enrica Detragiache, 1998, Financial Liberalization and Financial Fragility, Policy Research Working Paper \#1917, Washington DC: World Bank.

Dunning, John, 1980, Toward an Eclectic Theory of International Production: Some Empirical Tests, Journal of International Business Studies, Spring/Summer:9-31.

Eichengreen, Barry, Andrew K. Rose, and Charles Wyplosz, 1995, Exchange Market Mayhem: The Antecedents and Aftermath of Speculative Attacks, Economic Policy, October 1995:251312.

Euh, Yoon-Dae and James C. Baker, 1990, The Korean Banking System and Foreign Influence, London and New York: Routledge

Faruqi, Shakil, 1994, Financial Sector Reforms, Economic Growth, and Stability, Washington DC: World Bank.

Fieleke, Norman, 1977, The Growth of U.S. Banking Abroad: An Analytical Survey, Federal Reserve Bank of Boston, Conference Series, Key Issues in International Banking, 18: 9-40.

Goldberg, L.G., and A. Saunders, 1980, The Causes of U.S. Banks Expansion Overseas: The Case of Great Britain, Journal of Money, Credit and Banking, November: 630-643.

Goldberg, L.G. and A. Saunders, 1981, Determinants of Foreign Banking Activity in the US, Journal of Banking and Finance, 5:678-684.

Gray, J., and P. Gray, 1981, The Multinational Bank: A Financial MNC?, Journal of Banking and Finance, March: 33-63.

Grubel, G.H., 1977, A Theory of Multinational Banking, Banco Nazional del Lavoro: Quarterly Review, December: 349-363.

Kaminsky, Graciela and Carmen M. Reinhart, 1996, The Twin Crises: The Causes of Banking and Balance-of-Payments Problems, International Finance Discussion Papers \#544, Washington DC: Board of Governors of the Federal Reserve System.

Khoury, Sarkis, 1980, Dynamics of International Banking, New York: Praeger Publishers.

Khoury, Sarkis, 1979, International Banking: A Special Look at Foreign Banks in the U.S., Journal of International Business Studies, Winter:36-52.

Khoury, Sarkis, and Robert Piroge, 1983, An Economic Analysis of the Demand for Trade Loans from Multinational Banks, Business Economics, September: 40-45. 
Kim, Taehoo, 1990, Internationalization of Banking: With Special Reference to the Case of Korea, Journal of Economic Development 15, 1:63-82, June 1990.

Kim, In Kie, 1982, Foreign Banks and Monetary Policy, Journal of Economic Development, 175194, July 1982

Lindgren, Carl-Johan, Gillian Garcia, and Matthew Saal, 1996, Bank Soundness and Macroeconomic Policy, Washington DC: International Monetary Fund.

Minsky, Hyman P., 1986, Stabilizing an Unstable Economy, New Haven: Yale University Press.

Nascimento, Jean-Claude, 1991, Crisis in the Financial Sector and the Authorities= Reaction: The Philippines, in T. Balino and V. Sundararajan, eds., Banking Crises: Cases and Issues, Washington DC: International Monetary Fund.

Odle, Maurice, 1981, Multinational Banks and Underdevelopment, New York: Pergamon.

Perez-Campanero, Juan and Alfredo Leone, 1991, Liberalization and Financial Crises in Uruguay, 1974-87, in T. Balino and V. Sundararajan, eds., Banking Crises: Cases and Issues, Washington DC: International Monetary Fund.

Sabi, Manijeh, 1996, Comparative Analysis of Foreign and Domestic Bank Operations in Hungary, Journal of Comparative Economics 22:176-188.

Sabi, Manijeh, 1994, Motivational Factors for the Establishment of U.S. Banks in Developing Countries, Social and Economic Studies 43 (2):91-105

Sabi, Manijeh, 1988, An Application of the Theory of Foreign Direct Investment to Multinational Banking in LDCs, Journal of International Business Studies 19: 443-447.

Sabirin, Syahril, 1991, Indonesia=s Financial Reforms: Challenges in the 1990s for Its Banking and Financial Markets, Journal of Asian Economics 2, 2: 383-397, 1991.

Saunders, Anthony, 1986, Why Banks Go Abroad, Skandinaviska, Enskilda Banken Quarterly Review, 1:4-8.

Shea, Jia-Dong, 1994, @Taiwan: Development and Structural Change of the Financial System.@ In H.T. Patrick and Y.Ch. Park, Eds., The Financial Development of Japan, Korea, and Taiwan, New York: Oxford University Press, 1994 
Sheng, Andrew, 1996, Bank Restructuring: Lessons from the 1980s, Washington DC: World Bank

Terrell, Henry, 1979, U.S. Banks in Japan and Japanese Banks in the U.S.: An Empirical Comparison, Federal Reserve Bank of San Francisco, Economic Review, Summer:18-30.

Terrell, Henry, 1986, The Role of Foreign Banks in Domestic Banking Markets, in H. Cheng, ed., Financial Policy and Reform in Pacific-Rim Countries, Lexington MA: Lexington Books.

Tschoegl, Adrian, 1987, International Retail Banking as a Strategy: An Assessment, Journal of International Business Studies 19 (2): 67-88.

UNCTC, 1982, The Regulation of Transnational Banks in Developing Countries, New York; UNCTC.

UNCTC, 1981, Transnational Banks: Operations, Strategies and Their Effects in Developing Countries, New York: UNCTC.

Velasco, Andres, 1991, Liberalization, Crisis, Intervention: The Chilean Financial System, 197585, in T. Balino and V. Sundararajan, eds., Banking Crises: Cases and Issues, Washington DC: International Monetary Fund.

Wall Street Journal (WSJ), 1991, Foreign Banks in South Korea, November 29, 1991.

Wall Street Journal (WSJ), 1997, Foreign Banks Target the Little Guy in L.A., October 09, 1997.

Wall Street Journal (WSJ), 1992, Foreign Banks Post 37\% Rise in Earnings in South Korea for '91, April 06, 1992.

Wall Street Journal (WSJ), 1995, Foreign Banks Profit in Korea, January 30, 1995.

Weller, Christian, 1999, Financial Liberalization, Multinational Banks and Declining Real Credit: The Case of Poland, forthcoming in International Review of Applied Economics.

Weller, Christian, and Mark Scher, 1999, Multinational Banks and Development Finance, Center for European Integration Studies Working Paper, forthcoming.

Yang, Ya-Hwei, 1994, @Taiwan: Development and Structural Change of the Banking System@. In H. T. Patrick and Y. Ch. Park, Eds., The Financial Development of Japan, Korea, and Taiwan, New York: Oxford University Press. 
